\title{
Adsorption of 2-Nitrophenol onto Water Hyacinth Activated Carbon-Kinetics and Equilibrium Studies
}

\author{
Tina. O. Isichei ${ }^{1} \&$ Felix. E. Okieimen ${ }^{2}$ \\ ${ }^{1}$ Industrial Safety \& Environmental Tech. Dept., Petroleum Training Institute Effurun, Delta State, Nigeria \\ ${ }^{2}$ Geo-.Environmental and Climate Change Adaptation Research Center, University of Benin, Benin City, \\ Nigeria \\ Correspondence: Tina. O. Isichei, Industrial Safety \& Environmental Techology Department, Petroleum Training \\ Institute Effurun, Delta State, Nigeria. E-mail: bukkyisichei@yahoo.com
}

Received: November 15, 2013 Accepted: December 10, $2013 \quad$ Online Published: September 28, 2014

doi:10.5539/ep.v3n4p99

URL: http://dx.doi.org/10.5539/ep.v3n4p99

\begin{abstract}
Water hyacinth is an abundant bio-resource considered by many to be an environmental nuisance. It is found in almost all the creeks and waterways in the Niger Delta region of Nigeria known for its oil exploration activities and also in many other parts of the country. This work examines the preparation of activated carbon from water hyacinth by chemical activation using ammonium chloride at $400^{\circ} \mathrm{C}$ at a heating rate of $10{ }^{\circ} \mathrm{C} /$ minute and a dwell time of lhour thereby giving the plant an economic value. The adsorption equilibrium and kinetics of 2-nitrophenol on the water hyacinth activated carbon prepared was then carried out at $28{ }^{\circ} \mathrm{C}$ under varying experimental conditions of contact time, concentration and adsorbent dosage. The equilibrium data were fitted into the Freundlich and Langmuir adsorption isotherm model and two simplified kinetic models pseudo first order and pseudo -second order equations were applied to examine the kinetics of adsorption. The results showed that the equilibrium data fitted well into the Langmuir adsorption isotherm and the kinetics data fitted more into the pseudo -second order kinetic model. The equilibrium data were also examined using intra-particle diffusion model and it was observed that the rate of adsorption of 2-nitrophenol unto WHAC from aqueous solution is particle diffusion controlled, its diffusivity is independent of the extent of diffusion and the rate of adsorption is a function of initial concentration.
\end{abstract}

Keywords: water hyacinth, water hyacinth activated carbon (WHAC), activated carbon, isotherms, adsorption, equilibrium, kinetics, intra-particle diffusion

\section{Introduction}

Nitrophenols are important and versatile organic compounds in industrial, agricultural and defense applications. They are frequently used as intermediates in the manufacture of explosives, pharmaceuticals, pesticides, pigments, dyes, rubber chemicals and so on (Uberoi \& Bhattacharya, 1997). They are produced by microbial hydrolysis of several organophosphorous pesticides, such as parathion (Sethunathan, 1973; Nelson, 1982) or by photodegradation of pesticides that contain the nitrophenol moiety (Haghighi-Podeh, Bhattacharya \& Qu 1995; USEPA, 1980). Although the occurrence of nitrophenols in the atmosphere is usually through man made activities, it could also result from natural processes in the biosphere and nitrophenols are now common pollutants in several ecosystems in developed countries (Blasco \& Castillo, 1992). The compounds o-nitrophenol, p-nitrophenol and 2,4-dinitrophenol are listed on the United State Environmental Protection Agency's (USEPA's) "Priority Pollutants List" (Eckenfelder, 1989), therefore, the monitoring of o-nitrophenol is essential for environmental pollution control.

2-Nitrophenol specifically is used mainly as an intermediate for the production of dyestuffs, pigments, rubber chemicals, and fungicides. Nitrophenol has been detected in effluents from photographic and electronics industries (Bursey \& Pellizzari, 1982) and effluents from other chemical plants, both 2-nitrophenol and 4-nitrophenol were detected in the final effluent from the wastewater of a petroleum refining industry (Snider and Manning, 1982).

Nitrophenols have also been identified in primary and secondary effluents of municipal waste water treatment plants for example, both 2 and 4-nitrophenols were identified in the secondary effluent from a wastewater 
treatment plant in Sauget, Illinois, (Ellis, Jone \& Larson, 1982) and in recent times. Nitrophenols have also been found in dew waters (Rubio, Lissi, Herrera, Perez \& Fuentes, 2012)

2-Nitrophenol poses significant health risks since it is highly toxic to mammals, microorganisms and anaerobic bacteria. Its toxicity is thought to be due to the nitro group being easily reduced by enzymes to a nitro anion radical, nitroso and hydroxylamine derivatives (Uberoi \& Bhattacharya, 1997; Karim \& Gupta, 2001 \& 2002). These derivatives are responsible for the cytotoxic, mutagenic and carcinogenic action of nitro compounds (Workman, Walton \& Lee, 1986; Guissani, Henry, Lougmani \& Hickel, 1990).

The need for compliance with strict environmental protection agencies regulations in a most economic way has led to the continuous evolution of and development of wastewater treatment technologies. Over the years adsorption has been developed as a well established and powerful technique for the removal of organic pollutants from wastewaters and adsorption unto activated carbon has emerged as an efficient and economically viable technology in secondary wastewater treatment processes for the removal of final traces of a broad spectrum of toxic organic compounds from domestic and industrial wastewater especially when the activated carbon is produced from locally available bio-resources classified as wastes.

Precursor materials for the commercial activated carbons are coal, lignite, nutshells, wood and peat, which are transformed to carbonaceous materials by proper carbonization (Daifullah \& Griggs, 1997), although almost any organic matter with a large percentage of carbon could theoretically be activated to enhance its sorption characteristics. Many researchers globally have worked on production of activated carbon from plant biomass which are renewable resources, using low cost methods.

The use of agricultural by products to produce activated carbon is highly beneficial to the environment in at least three ways. One obvious benefit is the reduction of the waste load on landfills, because waste materials that are otherwise disposed can be recycled. Another merit is the preservation of scarce and valuable raw materials such as coal, lignite and petroleum coke, which are commonly used for commercial activated carbon production. Substitution of waste materials can make these raw materials available for other purposes (e.g., power generation). Above all, the end product (activated carbon) of this waste transformation technology is a highly porous material that can be an excellent adsorbent, filter bed, and biological support media for contaminant removal (Toles, Marshall \& Johns, 1998; Malik, 2004). Producing activated carbon from agricultural by-products is closely aligned with the millennium development goals of sustainable development.

Nitrophenols have been removed from aqueous solution through adsorption unto activated carbon cloth (Ayranci \& Duman, 2005), activated carbon fiber (Tang, Zheng, Lin, Luan \& Zhang, 2007) and sawdust (Larous \& Meniai, 2013)

The aim of this work is to use water hyacinth a low cost bio- resource to produce activated carbon which will then be used to adsorb 2-nitrophenol from aqueous solution thus expanding the scope of the bio-resources that can be used to prepare activated carbons for the adsorption of organics from aqueous solution.

\section{Materials and Methods}

The plant used was collected from Macaiva River in Warri South Local Government area of Delta State.

The roots and leaves of the plants were cut off and discarded while the stems were used for the preparation.

The stems were chopped into pieces, dried for about 5-7days until they were crispy and ground in a hammer mill. The ground sample was then impregnated with a saturated solution of ammonium chloride and dried before activation/carbonization.

The activation/carbonization was done at $400{ }^{\circ} \mathrm{C}$ and at a heating rate of $10{ }^{\circ} \mathrm{C} /$ minute and a dwell time of 60 minutes using a Carbolite Type 301 furnace (Thermal Engineering Services UK).

The activated sample was then washed with copious amounts of distilled water until the effluent from it was neutral to litmus, they were then oven- dried at $102-105{ }^{\circ} \mathrm{C}$ and ground into the particle size for powdered activated carbon. The water hyacinth activated carbons were analyzed for $\mathrm{pH}$, particle size distribution, iodine number (surface area), ash content, moisture content, abrasion resistance, surface charge, bulk density and tamped density using standard procedures (Toles, Marshall \& John, 1999; ASTM 15 (01) 1986).

\subsection{Chemicals}

Analytical grade 2 -nitrophenol supplied by BDH chemicals was used. A stock solution of $1000 \mathrm{mg}^{-1}$ was prepared by dissolving $1.000 \mathrm{~g}$ of 2-nitrophenol in distilled water and it was then diluted to $1000 \mathrm{~cm}^{3}$. All other intermediate solutions were prepared from this stock solution. 


\subsection{Effect of Adsorbent Dosage}

The effect of WHAC mass on 2-nitrophenol removal was investigated by contacting $100 \mathrm{~cm}^{3}$ of 2-nitrophenol solution with an initial concentration of $75 \mathrm{mg} \mathrm{l}^{-1}$ with different weighed masses $(0.2,0.4,0.6,0.8,1.0,1.2,1.4$, $1.6 \mathrm{~g}$ ) of WHAC in a stoppered conical flask. Each flask was then agitated for $5 \mathrm{hrs}$ at $28{ }^{\circ} \mathrm{C}$ and an oscillation rate of 500rev/min using a Rotalab flask shaker. The samples were then filtered through a Whatmann No 2 filter paper and analyzed using a colorimetric method (APHA, 1975) by measuring the absorbance at a wavelength of $500 \mathrm{~nm}$ using a UV-VIS spectrophotometer.

\subsection{Adsorption Equilibrium}

Equilibrium studies were done by contacting $1.0 \mathrm{~g}$ of WHAC with $100 \mathrm{~cm}^{3}$ solutions of 2-nitrophenol with different initial concentrations ranging from $20-160 \mathrm{mg} \mathrm{l}^{-1}$ in $250 \mathrm{~cm}^{3}$ conical flasks and agitating for $5 \mathrm{hrs}$ at 28 ${ }^{\circ} \mathrm{C}$ and an oscillation rate of $500 \mathrm{rev} / \mathrm{min}$ using a Rotalab Flask Shaker. After equilibrium was attained the concentrations of 2-nitrophenol in the samples were analyzed as described in section 2.2.

\subsection{Adsorption Kinetics}

Kinetics studies were done by contacting 2-nitrophenol solutions of $50 \mathrm{mg} \mathrm{l}^{-1}$ and $75 \mathrm{mg} \mathrm{l}^{-1}$ with WHAC at $1.00 \%$ level of application $\left(1 \mathrm{~g} / 100 \mathrm{~cm}^{3}\right)$. Samples were then pipetted out at different time intervals ranging from 15 minutes to 360 minutes. The collected samples were then analyzed for their concentrations of 2-nitophenol as described in section 2.2 .

\section{Results and Discussion}

The results of the physico- chemical characteristics of the water hyacinth activated carbon are presented in Table $1:$

Table 1. Characteristics of WHAC Carbonized at $400^{\circ} \mathrm{C}$ with a heating rate of $10^{\circ} \mathrm{C} / \mathrm{min}$ and a dwell time of $1 \mathrm{hr}$

\begin{tabular}{ll}
\hline Parameter & Value \\
\hline Yield (\%)-dry weight basis & $41.06 \pm 0.12$ \\
$\mathrm{pH}$ & $2.31 \pm 0.04$ \\
Moisture Content (\%) & $8.58 \pm 0.11$ \\
Ash Content (\%) & $9.89 \pm 1.00$ \\
Tamped Density gcm ${ }^{-3}$ & $0.224 \pm 009$ \\
Abrasion Resistance (\%) & $86.73 \pm 0.39$ \\
Iodine No. (Surface area) $\mathrm{mg} \mathrm{g}^{-1}$ & $454.72 \pm 2.72$ \\
Surface Charge (moles $\mathrm{H}^{+} \mathrm{g}^{-1}$ ) & $0.551 \pm 0.002$ \\
\hline
\end{tabular}

\section{Nomenclature}

$\boldsymbol{b}$-adsorption energy constant of Langmuir adsorption isotherm $\left(\mathrm{mg}^{-1}\right)$

$\boldsymbol{C}_{\mathbf{0}}$-initial liquid phase concentration $\left(\mathrm{mg} \mathrm{l}^{-1}\right)$

$\boldsymbol{C}_{\mathrm{e}}$-equilibrium liquid phase concentration $\left(\mathrm{mg} \mathrm{l}^{-1}\right)$

$\boldsymbol{k}_{1}$ rate constant of first-order adsorption $\left(\mathrm{min}^{-1}\right)$

$\boldsymbol{k}_{2}$.rate constant of second-order adsorption ( $\mathrm{g} / \mathrm{g}$ min)

$\boldsymbol{K}_{\mathbf{F}}$-Freundlich isotherm constant related to adsorption capacity $\left[\left(\mathrm{mg}^{1-1 / n} 1^{1 / n} \mathrm{~g}^{-1}\right]\right.$

$\boldsymbol{n}$ - Freundlich isotherm constant related to adsorption intensity

$\boldsymbol{q}_{\mathrm{e}}$-equilibrium solid phase adsorbate concentration $\left(\mathrm{mg} \mathrm{g}^{-1}\right)$

$\boldsymbol{q}_{\boldsymbol{t}}$-amount of adsorption at time $t\left(\mathrm{mg} \mathrm{g}^{-1}\right)$

$\boldsymbol{Q}$ - the maximum surface coverage (formation of monolayer) of sorbent ( $\mathrm{mg} \mathrm{g}^{-1}$ ) 
$\boldsymbol{R}_{\mathbf{L}^{-}}$dimensionless separation factor

$r^{2}$-correlation coefficient

$\boldsymbol{V}$-volume of solution (1)

$W$ - mass of adsorbent $(\mathrm{g})$

\section{Subscripts}

exp- experimental

cal-calculated

\subsection{Effect of Contact Time and Initial Concentration}

It was observed that adsorption increased with increasing concentration of adsorbate, the adsorption was also very rapid with the bulk occurring in $15 \mathrm{mins}$. As can be seen from Figure 1 for the lower concentration of $50 \mathrm{mg}$ $1^{-1}$ about $90 \%$ of the sorption took place in the first 15 mins and $100 \%$ sorption was attained in $3 \mathrm{hrs}$, showing that the adsorbate is effective at removing completely 2 nitrophenol at this level of concentration. For the higher concentration of $75 \mathrm{mg} \mathrm{l}^{-1}$ it was also observed that over $80 \%$ of the total adsorption took place in the first $15 \mathrm{mins}$ while it took a longer time to attain equilibrium. This may be because, since the number of adsorptions sites available for both concentrations are the same as a result of the equal amount of adsorbent used, the lower concentration with less molecules will have an increased sorption rate so it is adsorbed faster. Agitation was stopped after 5hours for both concentrations and it was observed that while $100 \%$ sorption was attained in 3hours for the concentration at $50 \mathrm{mg} \mathrm{l}^{-1}$, complete sorption could not be attained even after $5 \mathrm{hrs}$ for the concentration at $75 \mathrm{mg} \mathrm{l}^{-1}$. Perhaps it would have been possible to attain a higher level of adsorption with longer contact times. The results from Figure 1 also show that WHAC is effective in adsorbing 2-nitrophenol in the concentration range used in this experiment $50-75 \mathrm{mgl}^{-1}$ and that it is possible to achieve a $100 \%$ sorption when the concentrations of 2-nitrophenol is $\leq 50 \mathrm{mg} \mathrm{l}^{-1}$ at an adsorbate concentration of $1 \mathrm{~g} / 100 \mathrm{~cm}^{3}$ with a contact time of $3 \mathrm{hrs}$.

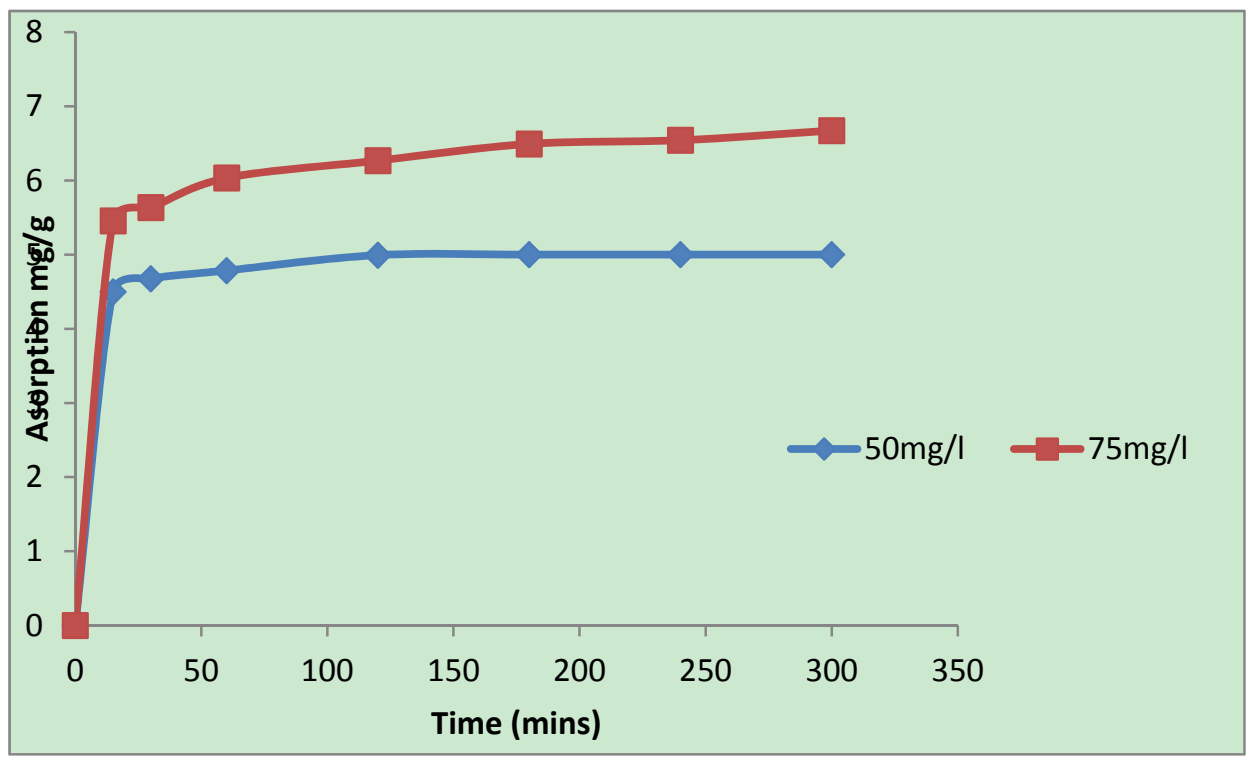

Figure 1. Effect of contact time and initial concentration on the adsorption of 2-nitrophenol onto WHAC at $28^{\circ} \mathrm{C}$

\subsection{Effect of Adsorbent Dosage}

It was observed that the adsorption of 2 nitrophenol increased with the increase in adsorbent dosage as shown in Figure 2. This can be attributed to increased adsorbent surface area and availability of more adsorption sites resulting from the increased adsorbent dosage. It was also observed that at the concentration of $75 \mathrm{mgl}^{-1}$, an equilibrium was reached at a concentration of $1 \mathrm{~g}$ adsorbent $/ 100 \mathrm{~cm}^{3}$ of adsorbate such that further increase in adsorbent dosage did not affect the amount of nitrophenol adsorbed. Maximum percentage removal was found to be about $91 \%$ and it was achieved with $1 \mathrm{~g}$ of adsorbate. 


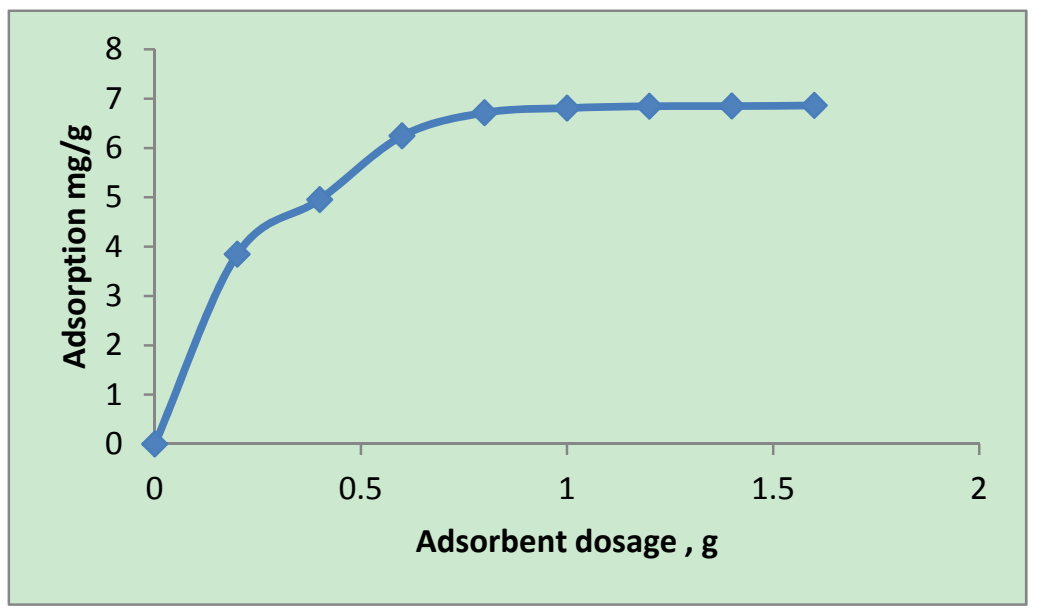

Figure 2. Effect of adsorbent dosage on the adsorption of 2 nitrophenol of $75 \mathrm{mgl}^{-1}$ onto WHAC at $28^{\circ} \mathrm{C}$

\subsection{Adsorption Equilibrium}

Adsorption isotherms are probably the best methods to determine the amount of adsorbate that an adsorbent can retain and that remaining in the solution after equilibrium, they also provide information on the capacity of the adsorbent. Langmuir and Freundlich isotherms are commonly used for the study of adsorption of phenols on activated carbon and they were used for this work. Adsorption isotherms also help provide basis for the design of adsorption systems. Adsorption isotherms are characterized by certain constant values which express the surface properties and affinity of the adsorbent for different pollutants. They can also be used to compare the adsorptive capacities of the adsorbent for different pollutants.

\subsubsection{Langmuir Isotherm}

The Langmuir isotherm relates the adsorption of molecules on a solid surface to concentration of a medium above the solid surface at a fixed temperature. The Langmuir equation is valid for monolayer sorption onto a surface with a finite number of identical sites and is given by equation (1)

$$
q e=\frac{q m b c e}{1+b c e}
$$

Where $\mathbf{b}$ and $\mathbf{q}_{\mathbf{m}}$ are Langmuir parameters related to maximum adsorption capacity and free energy of adsorption, respectively. $\mathbf{C}_{\mathbf{e}}$ is the equilibrium concentration in the aqueous solution and $\mathbf{q}_{\mathbf{e}}$ is the equilibrium adsorption capacity of adsorbent.

A linear form of equation (1) above will give

$$
\frac{1}{q e}=\frac{1}{b q m} \frac{1}{C e}+\frac{1}{q m}
$$

OR

$$
\frac{C e}{q e}=\frac{1}{b q m}+\frac{C e}{q m}
$$

Based on equation (2) the Langmuir constant $\mathbf{b}$ and $\mathbf{q}_{\mathbf{m}}$ can be calculated by plotting a graph of $\frac{1}{q e}$ vs $\frac{1}{C e}$ while for equation (3) the same constants can be calculated by plotting a graph of $\frac{\mathrm{Ce}}{q e} \mathrm{vs} \mathrm{Ce}$

The essential characteristics of the Langmuir isotherm can be expressed in terms of a dimensionless equilibrium parameter $\left(\boldsymbol{R}_{\mathbf{L}}\right)$ (Hameed, Din \& Ahmad, 2006), which is defined by:

$$
\mathrm{R}_{\mathrm{L}}=\frac{1}{(1+b C o)}
$$

where $\mathbf{b}$ is the Langmuir constant and $\mathbf{C}_{\mathbf{0}}$ the highest adsorbate concentration $\left(\mathrm{mgl}^{-1}\right)$. The value of $\mathbf{R}_{\mathbf{L}}$ indicates 
the type of the isotherm to be either unfavorable $\left(\mathbf{R}_{\mathbf{L}}>1\right)$, linear $\left(\mathbf{R}_{\mathbf{L}}=1\right)$, favorable $\left(0<\mathbf{R}_{\mathbf{L}}<1\right)$ or irreversible $\left(\mathbf{R}_{\mathbf{L}}=0\right)$. An $\mathbf{R}_{\mathbf{L}}$ value within 0-1 shows the applicability of the Langmuir isotherm.

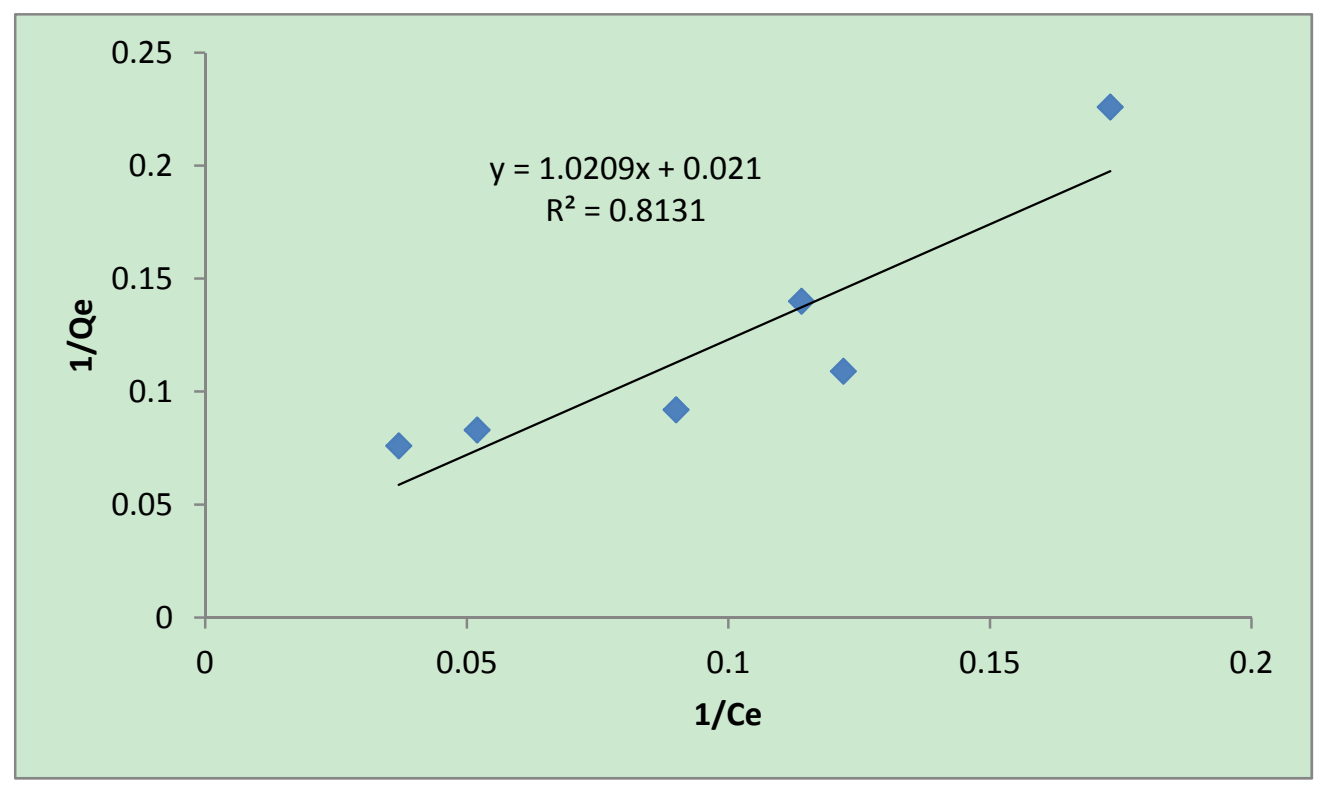

Figure 3. Langmuir isotherm for adsorption of 2-nitrophenol at various concentrations on WHAC from aqueous solution at $28^{\circ} \mathrm{C}$

From the plot in Figure 3, the Langmuir Constants $\mathbf{b}$ was calculated to be 0.0206 , while $\mathbf{q}_{\mathbf{m}}$ related to adsorption capacity was found to be $47.62 \mathrm{mg} \mathrm{g}^{-1}$, the correlation coefficient $\mathrm{r}$ was 0.9017 showing that the plot was linear, $\mathrm{R}_{\mathrm{L}}$ was also found to be 0.3268 showing the applicability of the Langmuir isotherm under the conditions used in this study.

\subsubsection{Freundlich Isotherm}

The Freundlich adsorption isotherm is used for heterogeneous surface energies system.

$$
q e=K_{F} C e^{1 / n}
$$

Where, $\mathbf{K}_{\mathbf{f}}$ and $\mathbf{1} / \mathbf{n}$ are Freundlich constants related to adsorption capacity and intensity of adsorption respectively. The linear form of the Freundlich equation becomes,

$$
\ln q e=\ln K F+\frac{1}{n} \ln C e
$$

OR

$$
\log q e=\log K F+\frac{1}{n} \log C e
$$

A plot of $\ln \left(\mathrm{q}_{\mathrm{e}}\right)$ vs. $\ln \left(\mathrm{C}_{\mathrm{e}}\right)$ would give the values of the Freundlich constants $\mathbf{K}_{\mathbf{f}}$ and $\mathbf{1} / \mathbf{n}$ and so would a plot of $\log \left(\mathrm{q}_{\mathrm{e}}\right)$ vs. $\log \left(\mathrm{C}_{\mathrm{e}}\right)$. The isotherm plot is shown in Figure 4: 


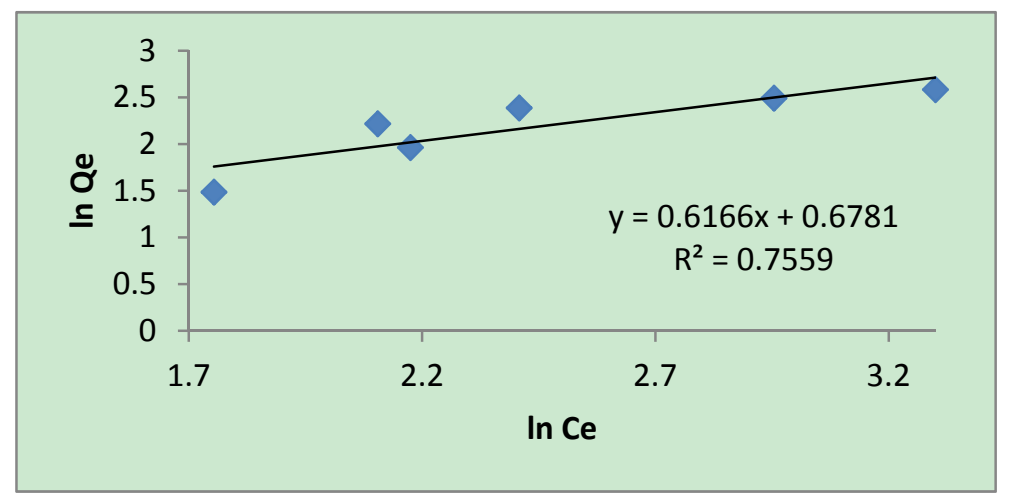

Figure 4. Freundlich isotherm for adsorption of 2-nitrophenol at various concentrations on WHAC from aqueous solution at $28^{\circ} \mathrm{C}$

From the plot in Figure 4 the Freundlich constants $\mathbf{K}_{\mathbf{F}}$ and $\mathbf{n}$ were calculated to be 1.97 and 1.623 respectively while the correlation coefficient $r$ was $0.8694 . \boldsymbol{n}$ gives an indication of how favorable the adsorption process is and $\boldsymbol{K}_{\mathrm{F}}$ is the adsorption capacity of the adsorbent. $\boldsymbol{K}_{\mathbf{F}}$ can be defined as the adsorption or distribution coefficient and represents the quantity of 2 nitrophenol adsorbed onto activated carbon adsorbent for a unit equilibrium concentration. The slope $1 / n$ ranging between 0 and 1 , is a measure of adsorption intensity or surface heterogeneity, becoming more heterogeneous as its value gets closer to zero (Haghseresht $\& \mathrm{Lu}, 1998$ ).

The magnitude of the exponent $\mathrm{n}$ gives an indication on the favorability of adsorption. It is generally stated that values of $\mathrm{n}$ in the range 2-10 represent good, 1-2 moderately difficult, and less than 1 poor adsorption characteristics (Dutta, Brothakur, \& Baruah, 1998; Banat, Al-Bashir, Al-asheh, \& Hayajneh, 2000). A value for $1 / n$ below one indicates a normal Langmuir isotherm while $1 / n$ above one is indicative of cooperative adsorption (Fytianos, Voudrias \& Kokkalis, 2000). The plot in Figure 4 shows a $1 / n$ value below 1 showing that the Langmuir isotherm best describes the adsorption process.

Table 2. Freundlich and Langmuir isotherm parameters

\begin{tabular}{ccccccc}
\hline \multicolumn{4}{c}{ Freundlich isotherm parameters } & \multicolumn{4}{c}{ Langmuir isotherm parameters } \\
\hline $\mathrm{K}_{\mathrm{F}}$ & $\mathrm{N}$ & $\mathrm{R}$ & $\mathrm{q}_{\mathrm{e}}(\mathrm{mg} / \mathrm{g})$ & $\mathrm{b}$ & $\mathrm{R}$ & $\mathrm{R}_{\mathrm{L}}$ \\
1.97 & 1.623 & 0.8694 & 47.62 & 0.0206 & 0.9017 & 0.2328 \\
\hline
\end{tabular}

\subsubsection{Isotherm Shapes}

The experimental adsorption isotherms of 2-nitrophenol from aqueous solutions onto WHAC is presented in Figure 5: 


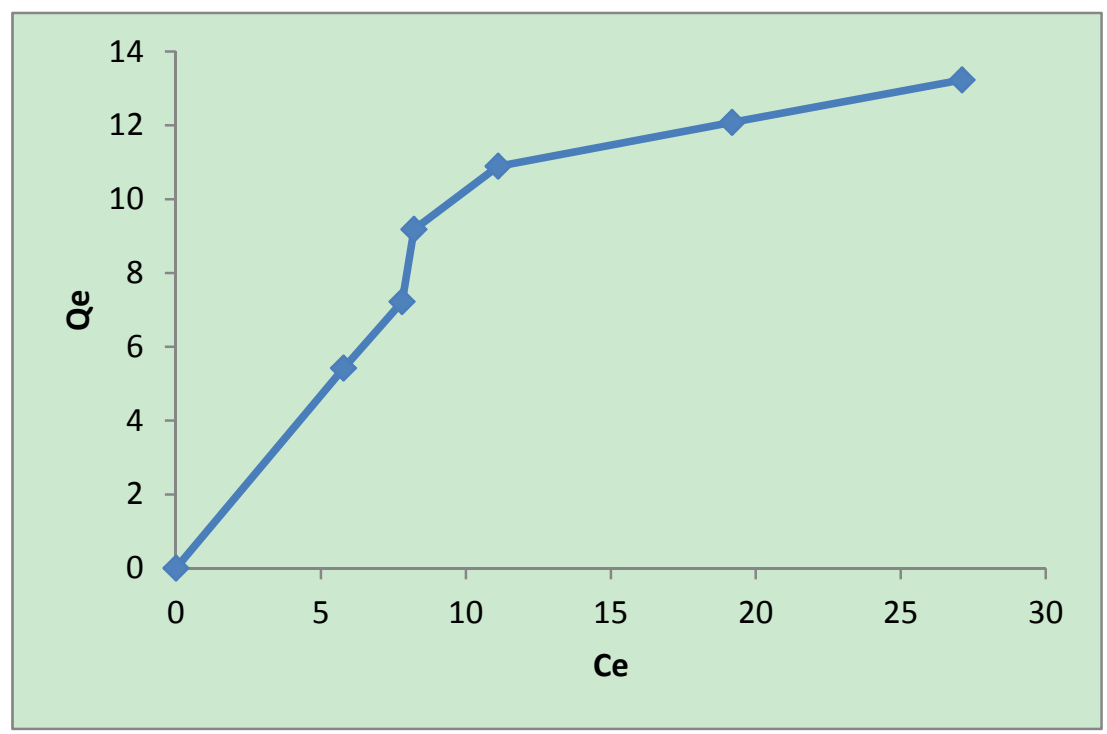

Figure 5. Adsorption isotherm of 2nitrophenol on WHAC

The shape of the isotherms is the first experimental tool to diagnose the nature of a specific adsorption phenomenon. Giles, MacEwan, Nakhwa \& Smith (1960) have classified adsorption isotherms into four main groups: L, S, H, and C. These four groups are classified based on the configuration of the initial part of the isotherm (i.e. class S, L, H, C) as shown in Fig.6 below. The subgroups relate to behavior at higher concentrations. The Langmuir class (L) is the most widespread in case of adsorption of phenolic compounds from water and it is characterized by an initial region which is concave to the concentration axis. Type L suggests that the aromatic ring adsorbs parallel to the surface and there is no strong competition between the adsorbate and the solvent to occupy the adsorption sites, According to the above classification, the isotherm of 2-nitrophenol displayed an $\mathrm{L}$ curve pattern. The $\mathrm{L}$ shape of the adsorption isotherm means that there is no strong competition between solvent (water) and the adsorbate (2-nitrophenol) to occupy the adsorbent (WHAC) surface sites. In this case, the longitudinal axes of the adsorbed molecules are parallel to the adsorbent surface (molecules adsorbed flat on the surface).

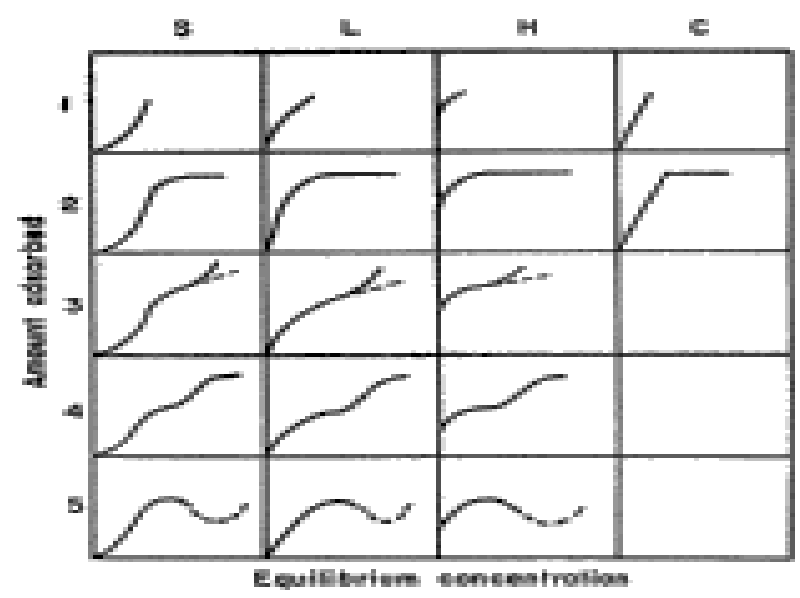

Figure 6. Classification of isotherm shapes (Giles et al, 1960)

\subsection{Adsorption Kinetics}

Kinetic models are used to examine the rate of the adsorption process and the potential rate -determining step and for this work in order to model the adsorption of phenol onto WHAC, pseudo first and second order kinetics models are applied.

The first order kinetic equation is expressed as 


$$
\frac{d q}{d t}=k_{1}(q e-q)
$$

where $\mathbf{q}_{\mathbf{e}}$ and $\mathbf{q}$ are the amounts of phenol adsorbed $(\mathrm{mg} / \mathrm{g}$ ) at equilibrium and at time $\mathrm{t}(\mathrm{min})$, respectively, and $\mathbf{k}_{\mathbf{1}}$ is the rate constant of pseudo-first-order sorption ( $\mathrm{min}$ ).

The integrated form of equation (8) becomes

$$
\ln \left(q_{e}-q\right)=\ln q_{e}-k_{1} t
$$

A plot of $\ln \left(q_{e}-\mathrm{q}\right)$ against $\mathrm{t}$ should give a linear relationship with the slope of $k_{1}$ and intercept of $\ln q_{e}$

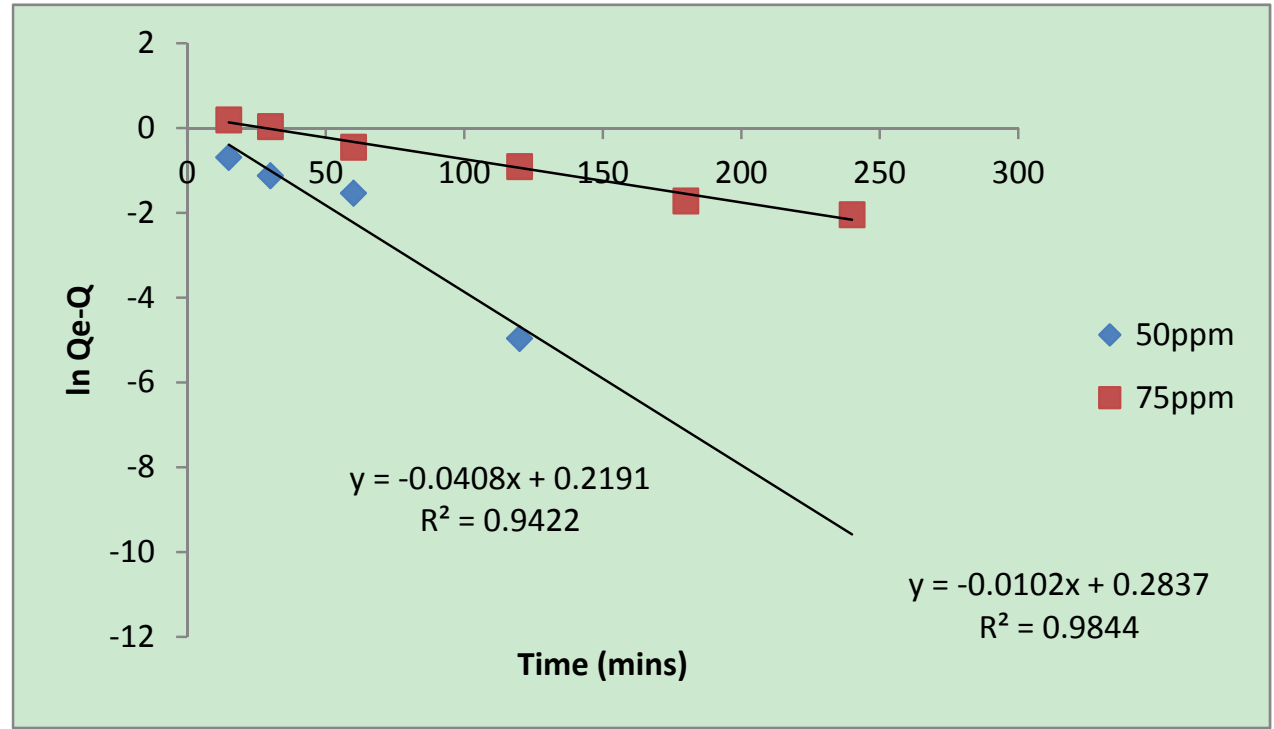

Figure 7. Pseudo-first order kinetics for the adsorption of 2-nitrophenol unto WHAC

As is shown in Figure 7 and the calculations for the value of $\mathrm{k} 1$ the pseudo first order rate constant, the amount of 2-nitrophenol adsorbed at equilibrium and the correlation coefficient $\mathbf{r}$ are also shown in Table 3:

Table 3. Pseudo-first order kinetic constants for the adsorption of 2 nitrophenol onto WHAC

\begin{tabular}{lllll}
\hline $\mathrm{C}_{\mathrm{o}}\left(\mathrm{mg} \mathrm{l}^{-1}\right)$ & $\mathrm{q}_{\mathrm{e}(\text { exptal })}(\mathrm{mg} / \mathrm{g})$ & $\mathrm{q}_{\mathrm{e}(\text { cal. })}(\mathrm{mg} / \mathrm{g})$ & $\mathrm{k}_{1}\left(\mathrm{~min}^{-1}\right)$ & $\mathrm{R}$ \\
\hline 50 & 5.0 & 1.245 & 0.040 & 0.9707 \\
75 & 6.672 & 1.327 & 0.010 & 0.9922 \\
\hline
\end{tabular}

The pseudo-second-order kinetic rate equation is expressed as follows (Ho \& Mckay, 1999)

$$
\frac{d q}{d t}=k_{2}(q e-q)^{2}
$$

Where $\mathrm{k}_{2}$ is the rate constant of pseudo-second-order sorption. The integrated form of equation (10) becomes

$$
\frac{t}{q}=\frac{1}{k_{2} q e^{2}}+\frac{1}{q e} t
$$

If second-order kinetics is applicable, the plot of $\mathbf{t} / \mathbf{q}$ versus $\mathbf{t}$ should show a linear relationship. There is no need to know any parameter beforehand and $\boldsymbol{q}_{\mathrm{e}}$ and $\boldsymbol{k}_{2}$ can be determined from the slope and intercept of the plot. Also, this procedure is more likely to predict the behavior over the whole range of adsorption. This plot is shown in Figure 6 below and from the graph $\boldsymbol{q}_{\mathbf{e}}$ and $\boldsymbol{k}_{2}$ were calculated and presented in Table 4 . 


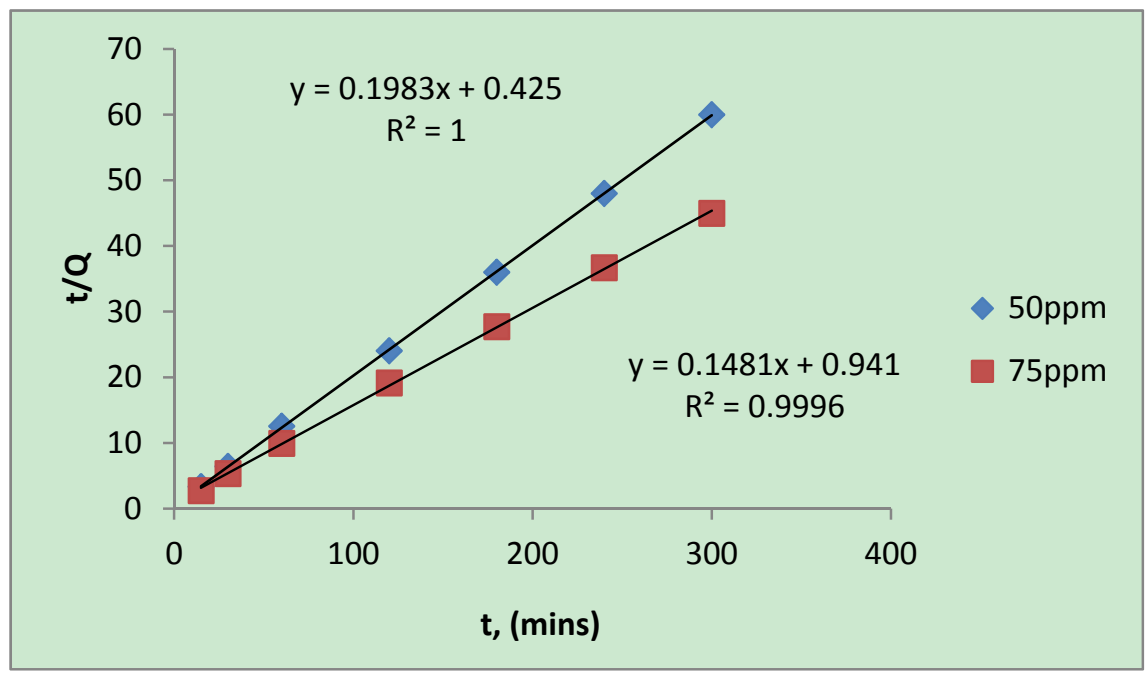

Figure 8. Pseudo-second order kinetics for adsorption of phenol on WHAC

Table 4. Pseudo-second order kinetic constants for the adsorption of 2 nitrophenol onto WHAC

\begin{tabular}{lllll}
\hline $\mathrm{C}_{\mathrm{o}}\left(\mathrm{mg} \mathrm{l}^{-1}\right)$ & $\mathrm{q}_{\mathrm{e}(\text { exptal })}(\mathrm{mg} / \mathrm{g})$ & $\mathrm{q}_{\mathrm{e}(\text { cal. })}(\mathrm{mg} / \mathrm{g})$ & $\mathrm{k}_{1}\left(\mathrm{~min}^{-1}\right)$ & $\mathrm{R}$ \\
\hline 50 & 5.0 & 5.051 & 0.3026 & 1 \\
75 & 6.672 & 6.757 & 0.1526 & 0.9998 \\
\hline
\end{tabular}

The results of the adsorption kinetics using the pseudo first and second order models as seen in Tables 3 and 4 show that the results model better the pseudo-second order since the values for $\mathbf{q}_{\mathbf{e} \text { (cal.) }}$ the solid phase adsorbent concentration at equilibrium compare very well with the experimental values $\mathbf{q}_{\mathbf{e}}$ (exptal) of the pseudo second order plot. The correlation coefficients were also better than those for the first order model as they were closer to unity. Secondly there was $100 \%$ adsorption of 2- nitrophenol solution at $50 \mathrm{mg} \mathrm{l}^{-1}$ onto WHAC at a $1 \%$ level of application and over $80 \%$ adsorption at a concentration of $160 \mathrm{mg}^{-1}$ showing that WHAC is applicable for the adsorption of 2nitrophenol over a wide range of concentration $20-160 \mathrm{mg} \mathrm{l}^{-1}$ as opposed to the results obtained in a similar work on adsorption of phenol onto WHAC where the applicability was only for phenols for concentrations $\geq 50 \mathrm{mg} \mathrm{l}^{-1}$ (Isichei \& Okieimen, 2012). This implies that WHAC may be suitable in secondary wastewater treatment processes with similar phenolic compounds as pollutants.

\subsection{Particle Diffusion}

The kinetic data shows that the sorption rate is a function of initial nitrophenol concentration. The sorption for the lower concentration of $50 \mathrm{mg} \mathrm{l}^{-1}$ was not only found to be faster than that of $75 \mathrm{mg} \mathrm{l}^{-1}$ but a $100 \%$ adsorption was achieved.The rate of attainment of equilibrium may be either film-diffusion controlled or particle diffusion controlled even though it has been recognized that there is no sharp distinction between the two mechanisms.

Vinod \&Amirudhan, (2001) used a linear driving force concept and developed a simple relationship for the particle-diffusion controlled sorption process.

$$
\ln (1-\alpha)=-\mathrm{k}_{\mathrm{p}} \mathrm{t}
$$

Here $\boldsymbol{\alpha}$ is the fractional attainment of sorption equilibrium and it is given as $\boldsymbol{x} / \boldsymbol{x} *$ where $\boldsymbol{x}$ is the amount of nitrophenol sorbed by a unit mass of WHAC at time $\mathrm{t}, \boldsymbol{x} *$ is the amount of nitophenol sorbed at equilibrium and $\mathrm{k}_{\mathrm{p}}$ is the rate coefficient for particle -diffusion control. A plot of $\ln (\mathbf{1 - \alpha})$ vs $\mathbf{t}$ should give a linear plot if equation (12) is applicable and the slope of the graph should give $\mathrm{k}_{\mathrm{p}}$.

It can be seen from Figure 9 that linear plots of $\ln (\mathbf{1 - \alpha})$ vs $\mathbf{t}$ were obtained throughout the range of $\boldsymbol{\alpha}$ values as shown by the correlation coefficient $\mathbf{r}$ of 0.9707 for $50 \mathrm{mg} \mathrm{l}^{-1}$ and 0.9962 for $75 \mathrm{mg}^{-1}$ respectively. 


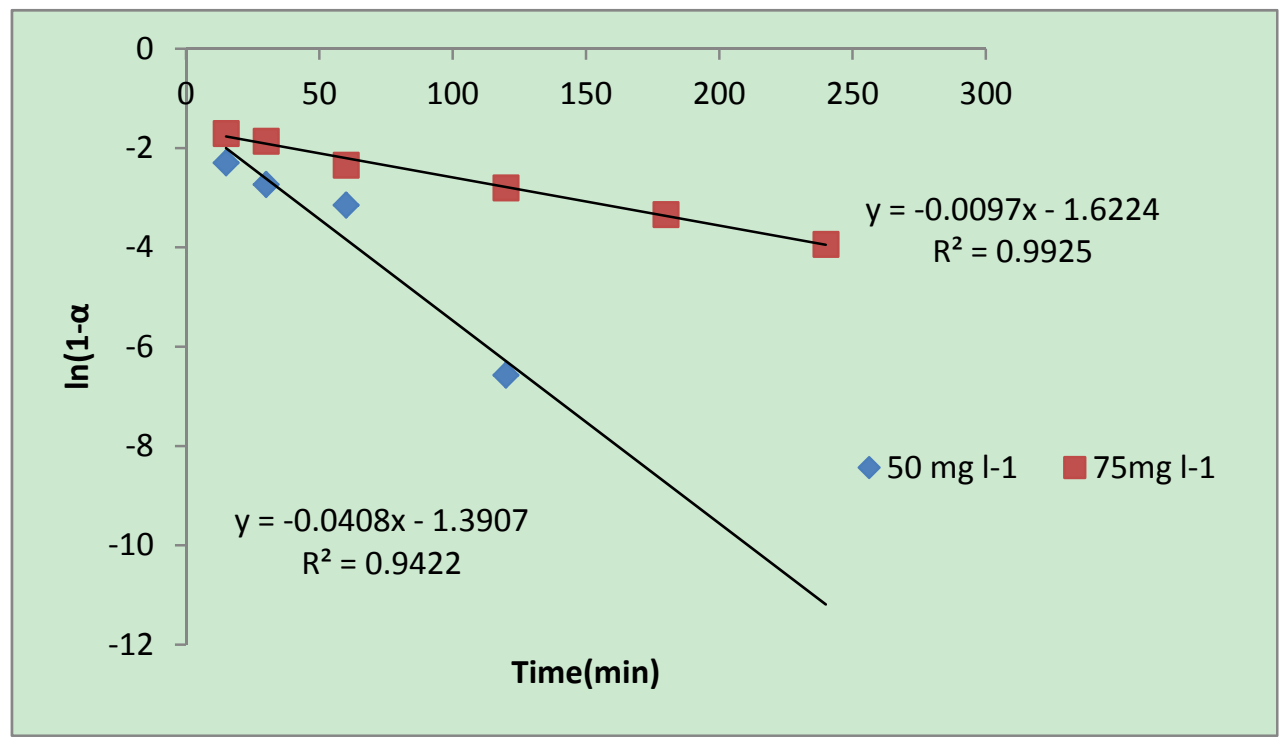

Figure 9. Sorption of 2 nitrophenol molecules by WHAC under particle-diffusion control

This showed that the rate of removal of 2 nitrophenol from aqueous solution with WHAC is particle-diffusion controlled and that its diffusivity in the WHAC would be independent of the extent of adsorption. From the slopes of the graphs in Figure 9 the values of $\mathrm{k}_{\mathrm{p}}$ were found to be $0.0408 \mathrm{~min}^{-1}$ and $0.0097 \mathrm{~min}^{-1}$ for initial concentrations of 50 and $75 \mathrm{mg} \mathrm{l}^{-1}$ respectively confirming that the rate of 2 nitrophenol adsorption onto WHAC is a function of initial concentration.

In a study by Shripal \&Mahesh (2006) where some priority organic pollutants namely phenol, o-cresol, pnitrophenol,, m-methoxyphenol, benzoic acid and salicyclic acid were adsorbed on granular activated carbon it was observed that p-nitrophenol was the most strongly adsorbed as compared to the other phenols studied. They observed that the solubility, molecular weight, nature and position of the substituent group all play a decisive role in the adsorption process, secondly their study showed that substituted phenols are adsorbed to a greater extent than phenol itself and also hydrophobic solutes are removed more rapidly as compared to hydrophilic solutes. These observations were also confirmed when the results from this study were compared with that from a previous study on adsorption of phenol on WHAC (Isichei \& Okieimen, 2012), which showed that 2 nitrophenol was better adsorbed on WHAC than phenol.

Adsorption of phenol, hydroquinone, m-cresol, p-cresol and p-nitrophenol from aqueous solutions onto high specific area activated carbon cloth has also been studied by Ayranci \& Duman (2005) and it was observed that the rate constants decreased in the order $\mathrm{p}$-nitrophenol approximately equal that of $\mathrm{m}$-cresol $>\mathrm{p}$-cresol $>$ hydroquinone approximately phenol. This seems to agree with that fact that the surface chemistry of activated carbons and the chemical characteristics of the adsorbate, such as polarity, ionic nature and functional groups determine the nature of bonding mechanisms and the extent of adsorption (Srivastava et al., 1997; Aksu \& Yener, 2001).

\section{Conclusion}

This study investigated the adsorption of 2-nitrophenol in aqueous solution onto water hyacinth activated carbon. The results show that the adsorption capacity of the adsorbent was affected by contact time, adsorbent dosage and initial concentration. The results also showed that under the experimental conditions of this study, WHAC was effective for adsorption of 2-nitrophenol over a range of concentrations from 20-160 $\mathrm{mg} \mathrm{l}^{-1}$.

The equilibrium data fitted well the Langmuir isotherm equation showing a monolayer adsorption of phenol unto water hyacinth activated carbon with a monolayer sorption capacity of $47.62 \mathrm{mg} / \mathrm{g}$.

The data obtained were also fitted into the pseudo -first order and pseudo -second order kinetic models and it was observed that the pseudo second -order equation provided a better fit for the adsorption data.

The data obtained were also fitted into the equation of the particle-diffusion controlled sorption process and it indicated that the rate of sorption on 2 nitrophenol onto WHAC is particle diffusion controlled.

It is believed from the results of this study that water hyacinth activated carbon would be effective in adsorbing 
phenols that are more hydrophobic, less soluble and with higher molecular weights than 2 nitrophenol especially in secondary wastewater treatment processes, however further work is need in this regard.

\section{References}

Aksu, Z., \& Yener, J. (2001). A comparative adsorption/biosorption study of mono-chlorinated phenols onto various sorbents. Waste Management, 21, 695-702. http://dx.doi.org/10.1016/S0956-053X(01)00006-X

American Standards for Testing and Materials (ASTM) 1986. Vol 15.01

APHA. (1975). Standard Methods for the Examination of Water and Waste Water (14th ed.). American Public Health Association/American Water Works Association/Water Environment Federation, Washington, D.C., USA.

Ayranci, E., \& Duman, O. (2005) Adsorption behaviors of some phenolic compounds onto high specific area activated carbon cloth. J Hazard Mater, 124(1-3), 125-132. http://dx.doi.org/10.1016/j.jhazmat.2005.04.020

Banat, F. A., Al-Bashir, B., Al-asheh., S., \& Hayajneh, O. (2000). Adsorption of phenol by bentonite. Env. Poll., 107, 391-398. http://dx.doi.org/10.1016/S0269-7491(99)00173-6

Blasco, R., \& Castillo, F. (1992) Light-dependent degradation of nitrophenols by the phototrophic bacterium Rhodabacter capsulatus EIFI. Appl. Environ. Microb., 58, 690-695.

Bursey, J. T., \& Pellizzari, E. D. (1982). Analysis of industrial wastewater for organic pollutants in consent decree survey. Contract No. 68-03-2867. Athens, GA: US EPA Environ Res Lab, 84.

Daifullah, \& Girgis, B. S. (1997) Removal of some substituted phenols by activated carbon obtained from agricultural waste. Water Research, 32, 1169-1177.

Dutta, N. N., Brothakur, S., \& Baruah, R. (1998). A novel process for recovery of phenol from alkaline wastewater: laboratory study and predesign cost estimate. Water Environ. Res., 70, 4-9. http://dx.doi.org/10.2175/106143098X126838

Eckenfelder, W. W. J. (1989). Industrial water pollution control (2nd ed.). McGraw-Hill; New York, NY.

Ellis, D. D., Jone, C. M., \& Larson, R. A. (1982). Organic constituents of mutagenic secondary effluents from wastewater treatment plants. Arch Environ Contam Toxicol, 11, 373-382.

Fytianos, K., Voudrias, E., \& Kokkalis, E. (2000). Sorption-desorption behavior of 2,4-dichlorophenol by marine sediments. Chemosphere, 40, 3-6. http://dx.doi.org/10.1016/S0045-6535(99)00214-3

Giles, C. H., MacEwan, T. H., Nakhwa, S. N., \& Smith, D. (1960) Studies in adsorption. Part XI. A system of classification of solution adsorption isotherms, and its use in diagnosis of adsorption mechanisms and in measurements of specific surface areas of solids. J. Chem. Soc., 10, 3973-3993. http://dx.doi.org/10.1039/jr9600003973

Guissani, A., Henry, Y., Lougmani, N., \& Hickel, B. (1990). Kinetic studies of four types of nitroheterocyclic radicals by pulse radiolysis: Correlation of pharmacological properties to decay rats. Free. Radical. Bio. Med. 8, 173-189. http://dx.doi.org/10.1016/0891-5849(90)90090-6

Haghighi-Podeh, M. R., Bhattacharya, S. K., \& Qu, M. (1995). Effects of nitrophenols on acetate utilizing methanorgenic system. Water. Res., 29, 391-399. http://dx.doi.org/10.1016/0043-1354(94)00193-B

Haghseresht, F., \& Lu, G. (1998). Adsorption characteristics of phenolic compounds onto coal-reject- derived adsorbents. Energy Fuels, 12, 1100-1107. http://dx.doi.org/10.1021/ef9801165

Hameed, B. H., Din, A. T. M., \& Ahmad, A. L. (2006). Adsorption of methylene blue onto bamboo-based activated carbon: Kinetics and equilibrium studies. J. of Hazardous Materials, 137, 695-699.

Hazardous Substances Data Bank (HSDB). (1989). National Library of Medicine. National Toxicology Information Program, Bethesda, MD.

Ho, Y. S., \& McKay, G. (1999). Pseudo-second order model for sorption process. Process Biochem, 34, 451-465. http://dx.doi.org/10.1016/S0032-9592(98)00112-5

Isichei, T. O., Okieimen, F. E. (2012). Adsorption of phenol onto water hyacinth activated carbon-kinetics and equilibrium studies. Journal of Environmental Chemistry and Ecotoxicology, 4(13), 234-241.

Karim, K., \& Gupta, S. K. (2001). Biotransformation of nitrophenols in up -flow anaerobic sludge blanket reactors. Bioresource Technol., 80, 179-186. http://dx.doi.org/10.1016/S0960-8524(01)00092-X

Karim, K., \& Gupta, S. K. (2002). Effects of alteration carbon sources on biological transformation of 
nitrophenols. Biodegradation, 13, 353-360. http://dx.doi.org/10.1023/A:1022364616575

Larous, S., \& Meniai, A. H. (2013) Elimination of organic pollutants from wastewater. Application to p-nitrophenol. Desalination and Water Treatment, 51, 5014-5020. http://dx.doi.org/10.1080/19443994.2013.795716

Malik, P. K. (2004). Dye removal from wastewater using activated carbon developed from sawdust: adsorption equilibrium and kinetics. J. Hazard. Mater. B., 113, 81-88. http://dx.doi.org/10.1016/j.jhazmat.2004.05.022

Nelson, L. M. (1982). Biologically induced hydrolysis of parathion in soil: isolation of hydrolyzing bacteria. Soil. Biol. Biochem., 14, 219-222. http://dx.doi.org/10.1016/0038-0717(82)90028-1

Rubio, M. A., Lissi, E., Herrera, N., Perez, V., \& Fuentes, N. (2012). Phenol and nitrophenols in the air and dew waters of Santiago de Chile. Chemosphere, 86(10), 1035-1039. http://dx.doi.org/10.1016/j.chemosphere.2011.11.046

Sethunathan, N. (1973). Degradation of parathion in flooded acid soil. J. Agr. Food. Chem., 21, 602-604. http://dx.doi.org/10.1021/jf60188a042

Singh, S., \& Yenkie, M. K. N. (2006). Scavenging of Priority Organic Pollutants from Aqueous Waste using Granular Activated Carbon. Journal of the Chinese Chemical Society, 53, 325-334.

Snider, E. H., \& Manning, F. S. (1982). A survey of pollutant emission levels in waste waters and residuals from the petroleum refining industry. Environ Int, 7, 237-258. http://dx.doi.org/10.1016/0160-4120(82)90114-3

Srivastava, S. K., Tyagi, R., Pal, N., \& Mohan, D. (1997). Process development for removal of substituted phenol by carbonaceous adsorbent obtained from fertilizer waste. Journal of Environmental Engineering, 123, 842-851. http://dx.doi.org/10.1061/(ASCE)0733-9372(1997)123:9(842)

Tang, D., Zheng, Z., Lin, K., Luan, J., \& Zhang, J. (2007). Adsorption of p-nitrophenol from aqueous solutions onto activated carbon fiber. $J$ Hazard Mater, 143(1-2), 49-56. http://dx.doi.org/10.1016/j.jhazmat.2006.08.066

Toles, C. A., Marshall, W. E., \& John, M. M. (1999). Carbon, 37, 1207-1214. http://dx.doi.org/10.1016/S0008-6223(98)00315-7

Toles, C. A., Marshall, W. E., \& Johns, M. M. (1998). Phosphoric acid activation of nutshells for metals and organic remediation: Process optimization. Journal of Chemical Technology \& Biotechnology, 72, 255-263. http://dx.doi.org/10.1002/(SICI)1097-4660(199807)72:3<255::AID-JCTB890>3.0.CO;2-P

Uberoi, V., \& Bhattacharya, S. K. (1997). Toxicity and degradability of nitrophenols in anaerobic systems. Water. Environ. Res., 69, 146-156. http://dx.doi.org/10.2175/106143097X125290

United States Environmental Protection Agency (USEPA). (1980). Ambient water quality criteria for nitrophenols. EPA-440/s-80-063.

Vinod, V. P., \& Amirudhan, T. S. (2001). Sorption of Tannic acid on Zirconium pillared Clay. J. Chem. Technol. Biotechnol., 77, 92-101. http://dx.doi.org/10.1002/jctb.530

Workman, P., Walton, M. L., \& Lee, F. Y. (1986). Benznidazole: nitroreduction and inhibition of cytochrome P-450 in chemosensitization of tumor response to cytoxic drugs. Biochem. Pharmacol., 35, 117-119. http://dx.doi.org/10.1016/0006-2952(86)90568-X

\section{Copyrights}

Copyright for this article is retained by the author(s), with first publication rights granted to the journal.

This is an open-access article distributed under the terms and conditions of the Creative Commons Attribution license (http://creativecommons.org/licenses/by/3.0/). 